\title{
Effect of Heat Compresses Hydrotherapy to Reduction of Pain Labor Stage 1st
}

\author{
Luluk Susiloningtyas, Fransiska Novitasari, Ratna Feti Wulandari \\ Pamenang Midwifery Academy, Kediri, Indonesia \\ luluksusiloningtyas@gmail.com
}

\begin{abstract}
Labor pain is an unpleasant stimulus that causes fear and worry. This situation will be stimulate an increase in catecholamineswhich can be cause interference with the strength of uterine contractions so that uterine insertion occurs if not corrected, which will be cause prolonged labor. That Incidence was 53\% from based on 2012 IDHS data so increasing was abnormalities in the physiology of labor and increase cesarean section labor, so that's necessary to prevent maternal care in the form of methods of pain transfer that can be increasecomfort to intranatalthat purposereducing the number of complications and stress in intranatal. The One non-pharmacological method is heat compresshydrotherapy. This aims was determine the effect heat compresseshydrotherapy to labor pain reduction of active process of phase I to intranatal in community health center of Puhjarak Kediri district. The type of research was used Quasi Experimental. withcross sectional approach. one group pretest-posttest design. The sampling technique was used accidental sampling. The independent variable was the provision of hot compress hydrotherapy and the dependent variable is the reduction of labor pain during the active phase. The instrument used for the dependent variable was the observation sheet. The instrument used for the independent variable was a tool / instrument for heat compress hydrotherapy. Analysis of data using the Wilcoxon Sign Rank. The results of data analysis stated that sig $(\mathrm{p})=0,000$ where $\alpha=0.05$, $\mathrm{p}<\alpha$, means that therewas an effect of giving heat compress hydrotherapy to the reduction of labor pain in the active phase. Correlation or influence using Wilcoxon Correlation =0.382 .
\end{abstract}

Keywords: Heat Compress Hydrotherapy, Labor, Pain

Received July, 25, 2019; Revised August 24, 2019; Accepted September 13, 2019 


\section{STRADA Jurnal Ilmiah Kesehatan}

DOI: $10.30994 /$ sjik.v8i2.223

ISSN: 2252-3847 (print); 2614-350X (online)

Vol.8 No.2. November 2019. Page.136-145

\section{BACKGROUND}

The first stage is the opening stage so that the progress of the first stage is assessed from the progress of the opening, even though in the first stage there is a process of decreasing the head and rotating the inside. Labor pain is a physiological process during labor but can also cause problems if it is not handled properly. Some of the problems that can arise if pain is not treated is stress in the mother which can stimulate the secretion of catecholamines. As a result of secretion of cotecholamines will cause inadequate uterine contractions, the fetus is at risk of fetal distress due to decreased uteroplacental perfusion, besides labor pain is one of the things that make the mother feel uncomfortable, causing disturbances in the strength of uterine contractions so that uterine insertion occurs if uncorrected, which will be cause prolonged labor. The One non-pharmacological method for reducing pain is with hot compress hydrotherapy. Hot water used in hydrotherapy provides a local vasodilation effect that can increase muscle relaxation and reduce the sensation of pain due to muscle stress (Mackey, 2001). With relaxation and comfort can be reduce stress hormones. Increased comfort and decreased production of stress hormones can increase uterine contractility. Several studies that use hydrotherapy in labor have proven that hydrotherapy can reduce the use of tools in labor and does not require a long time in women with dystocia. Hydrotherapy can increase relaxation, which is a technique that can be chosen to reduce pain, increase relaxation and comfort of birth mothers (Ika WidiAstuti, 2015)

Based on the explanation above, researchers was interested to do the research with the titlethe effect heat compresseshydrotherapy to labor pain reduction of active process of phase i to intranatal incommunity health center of Puhjarak Kediri district, which The expectation can be reduce pain, increase the comfort and serenity of mothers labor.

\section{OBJECTIVE}

This study aimed to determine the effect heat compresseshydrotherapy to labor pain reduction of active process of phase I to intranatal in community health center.

\section{METHODS}

Design

research studies used an experimental Quasi with a cross sectional one group pretest-posttest design.

Variable

This researchVariable of independent variables wasadministering heat compression hydrotherapy and dependent was labor pains.a reduction

\section{Subjects}

The population was all mothers in active process offirst phase of labor in Puhjarakthe Community Health Center in Kediri The research sample was part of intranatal in Puhjarak Health Center, Kediri Regency, from May to July 2019, the sampling technique used accidental sampling so that a sampleswere 20 respondents thatwere inclusionscriteria mothers willing to be respondents and intranatalof the first phase of Active process, then exclusions criteria were emergency intranatal (referral). 


\section{STRADA Jurnal Ilmiah Kesehatan}

DOI: $10.30994 /$ sjik.v8i2.223

Hydrotherapy

Giving hot compress hydrotherapy is a non-pharmacological technique for reducing labor pain with a heat compress on the lower back and lower abdomen of the birth mother, where respondents was given the action of hydrotherapy with heat compress instrument.

Reduction of labor pain

Labor pain is pain that was felt by the mother during labor in the first phase of the Active phase in labor. Assessed by observation using the pain scale. Called a reduction in pain if there was a decrease in criteria before and after heat compress hydrotherapy was given with criteria 0 no pain, 1-3 criteria of mild pain, 4-6 criteria of moderate pain, 7-9 severe pain criteria and 10 criteria of very severe pain.Measurement of the percentage of labor pain before hydrotherapy with heat compresses in the first stage of labor in the active phase.

Labor pain in the first-phase active mothers can be known from observations with pain scale before the respondent was given heat compress hydrotherapy then processed the data so that a percentage appears stating the percentage of pain criteria for labor. While labor pain after giving heat compressed hydrotherapy can be known from the observation of labor pain after giving hydrotherapy with pain scale for respondents in Puhjarak Health Center in Kediri district, then compared with pain before heat compressed hydrotherapy..

Statistic analysis

Bivariate analysis was used to determine the effect between independent and dependent variables. Data were analyzed using the Wilcoxon Sign Rank test. To determine whether there was an influence between the independent variable and the dependent variable, then using the $p$ value compared to the error rate used is $5 \%$ or 0.05 . If $p$ value $\leq 0.05$, then Ho was rejected, which means there was a significant influence between the independent variable and the dependent variable. While the level of correlation was uses Wilcoxon correlation.

Implementation of Ethics Test in Health Polytechnic Ministry of Health Malang.

\section{RESULTS}

The percentage of maternal pain in the active phase I Before giving heat compress hydotherapy:

Table 1. Labor pain during first phase of active process labor before giving hot compress hydrotherapy

\begin{tabular}{|l|l|c|c|}
\hline No & Criteria for Labor Pain & Frequency & $\begin{array}{l}\text { Percentage } \\
(\boldsymbol{\%})\end{array}$ \\
\hline 1. & No pain & 0 & 0 \\
2. & Mild Pain & 0 & 0 \\
3. & Moderate Pain & 0 & 0 \\
4. & Severe pain & 16 & 80 \\
5. & Very painful & 4 & 20 \\
\hline \multicolumn{2}{|l|}{ Total } & 20 & 100,00 \\
\hline
\end{tabular}

Based on the results of research conducted in Puhjarak Public Health Center, Kediri Regency on May 10 - July 31, 2019 before giving hydrotherapy from 20 respondents, it can be seen 


\section{STRADA Jurnal Ilmiah Kesehatan}

DOI: $10.30994 /$ sjik.v8i2.223

ISSN: 2252-3847 (print); 2614-350X (online)

Vol.8 No.2. November 2019. Page.136-145

that those who experience severe labor pain were 16 respondents $(80 \%)$ while some respondents were as many as 4 respondents $(20 \%)$ had very severe pain criteria

The percentage of maternal pain in the active phase I after giving heat compress hydotherapy

Table 2. Maternal pain in the first phase of active process after administration of heat compress hydrotherapy

\begin{tabular}{|l|l|c|c|}
\hline No & Criteria for Labor Pain & Frequency & $\begin{array}{l}\text { Percentage } \\
(\%)\end{array}$ \\
\hline 1. & No pain & 0 & 0 \\
2. & Mild Pain & 3 & 15 \\
3. & Moderate Pain & 16 & 75 \\
4. & Severe pain & 2 & 10 \\
5. & Very painful & 0 & 0 \\
\hline Jumlah & 20 & 100,00 \\
\hline
\end{tabular}

Based on the results of the study showed that labor pain in the first stage of labor in the active phase of the mother after giving heat compressed hydrotherapy most of the criteria wereas many as 15 respondents (75\%), and partlyie 3 respondents $(15 \%)$ had mild pain criteria and the other half were 2 respondents (10\%) had severe pain criteria

Effect of Hydrotherapy Heat Compress on Reduction of First Stage Active process Labor Pain in Puhjarak The Health Center in Kediri in 2019 was illustrated in the followed table:

\begin{tabular}{|c|c|c|c|c|c|c|c|c|c|c|c|c|}
\hline \multirow{2}{*}{\multicolumn{3}{|c|}{$\begin{array}{c}\text { Criteria for Labor Pain Before Hydrotherapy Hot } \\
\text { Compress }\end{array}$}} & \multicolumn{10}{|c|}{$\begin{array}{l}\text { Criteria for Labor Pain After } \\
\text { Hydrotherapy Hot Compress }\end{array}$} \\
\hline & & & \multicolumn{2}{|c|}{$\begin{array}{c}\text { No } \\
\text { pain }\end{array}$} & \multicolumn{2}{|c|}{$\begin{array}{l}\text { Mild } \\
\text { Pain }\end{array}$} & \multicolumn{2}{|c|}{$\begin{array}{l}\text { Modera } \\
\text { te Pain }\end{array}$} & \multicolumn{2}{|c|}{$\begin{array}{l}\text { Severe } \\
\text { pain }\end{array}$} & \multicolumn{2}{|c|}{$\begin{array}{c}\text { Very } \\
\text { painf } \\
1\end{array}$} \\
\hline & $\sum$ & & $\sum$ & & $\sum$ & $\%$ & $\sum$ & $\%$ & $\sum$ & $\%$ & & $\%$ \\
\hline No pain & 0 & 0 & 0 & 0 & 0 & 0 & 0 & 0 & 0 & 0 & 0 & 0 \\
\hline Mild Pain & 0 & 0 & 0 & 0 & 0 & 0 & 0 & 0 & 0 & 0 & 0 & 0 \\
\hline Moderate Pain & 0 & 0 & 0 & 0 & 0 & 0 & 0 & 0 & 0 & 0 & 0 & 0 \\
\hline Severe pain & 16 & 80 & 0 & 0 & 3 & 15 & 11 & 55 & 2 & 10 & 0 & 0 \\
\hline Very painful & 4 & 20 & 0 & 0 & 0 & 0 & 4 & 20 & 0 & 0 & 0 & 0 \\
\hline Total & 20 & $\begin{array}{c}10 \\
0\end{array}$ & 0 & 0 & 3 & 15 & 15 & 75 & 2 & 10 & 0 & 0 \\
\hline
\end{tabular}

Table 3. Cross Tabulation of the Effects of Hydrotherapy Heat Compresses on Reduction of First Stage Active Labor Pain in Puhjarak Community Health Center in Kediri 2019 Based on the table above showed that the respondent data The Effect of Giving Heat Compress Hydrotherapy For Reduction of Pain in First Stage of Active Labor in intranatal in Puhjarak Health Center in Kediri District respondents (80\%) and 4 respondents (20\%) experienced very severe pain criteria. After giving heat compressed hydotherapy, there was 


\section{STRADA Jurnal Ilmiah Kesehatan}

DOI: $10.30994 /$ sjik.v8i2.223

ISSN: 2252-3847 (print); 2614-350X (online)

Vol.8 No.2. November 2019. Page.136-145

a reduction in pain, namely respondents who experienced severe pain before being given hydrotherapy decreased, from a total of 16 respondents most experienced moderate pain, namely 11 respondents (55\%), criteria for severe pain as much as 2 respondents (10\%) and mild pain as many as 3 respondents $(15 \%)$ and no respondents $(0 \%)$ with very severe pain criteria. And respondents who had experienced very severe pain from a total of 4 respondents after being given hot compress hydrotherapy experienced a decrease in pain criteria that was as much as 4 respondents $(20 \%)$ with moderate pain criteria

The results of the statistical test of the research on the Effect of Giving Heat Compresses Hydrotherapy to the Reduction of First Stage Labor Pain Active Phase in Puhjarak Community Health Center in Kediri in 2019 are as follows: The results of Wilcoxon correlation calculations can be seen in the appendix

Table 4. Results of Statistical Tests for Giving Heat Compress Hydrotherapy Against Reduction of First Stage Active Labor Pain in Puhjarak Community Health Center Kediri 2019

\begin{tabular}{|l|rr|}
\hline & \multicolumn{1}{|c|}{$\begin{array}{c}\text { Pain after hydrotherapy (deceleration) } \\
-\end{array}$} \\
\hline$Z$ & Pain Before Hydrotherapy (deceleration) \\
\hline $\begin{array}{l}\text { Asymp.Sig. (2- } \\
\text { tailed) }\end{array}$ & & $-3,852 \mathrm{a}$ \\
\hline
\end{tabular}

a. Based on positive rank

b. Wilcoxon Signed RankTest

The results computer software Wilcoxon Correlation formula obtained $\rho$ value $=0,000 ; \rho$ $<\alpha$ then (H1) was accepted and (H0) was rejected, meaning that there wasan influence between giving a heat compress hydrotherapy to the reduction of labor pain when Active Phase I. With a Wilcoxon Correlation value of - 3, 852

Based on the results of statistical tests it can be concluded that there were differences in pain before and after hydrotherapy with $\mathrm{P}=0,000$. The results obtained showed that there was a decrease in the scale of labor pain after giving a hot compress of labor pain before and after therapy. Decrease in pain scale that occurs due to the application of hot compresses can facilitate blood circulation, reduce pain, provide warmth, comfort and calm. This shows a significant reduction in pain compared to those not using. Hot compress was one of the skin stimulation techniques that can provide an effective pain reduction effect. The workings of cutaneous stimulation, especially hot compresses, can cause endorphin release, thereby blocking the transmission of pain stimulus. Physiological effects of heat compresses are vasodilatory, relieve pain by relaxing muscles, increasing blood flow, having a sedative effect and relieving pain by getting rid of inflammatory products that cause pain (Mackey, 2001). In theory, a heat compress can be applied using a jar filled with water temperature of 41-43oC wrapped in a cloth, or using a cloth affixed to the area to be compressed for 20 minutes. Heat compresses applied to a woman's lower back in the area where the fetal head is pressing against the spine will reduce pain, heat will increase circulation to the area thereby improving tissue anoxia caused by pressure (Putri, Adyb. 2015) 


\section{STRADA Jurnal Ilmiah Kesehatan}

DOI: $10.30994 /$ sjik.v8i2.223

ISSN: 2252-3847 (print); 2614-350X (online)

Vol.8 No.2. November 2019. Page.136-145

\section{DISCUSSION}

\section{The percentage of maternal pain in the active phase I Before giving heat compress hydotherapy}

The delivery process was always associated with discomfort or pain during the delivery process. Pain that occurs during labor was caused by cervical stretching, uterine contractions and fetal decline that causes prostaglandin to be released which can cause pain. Pain that was not resolved can pose a physiological and psychological danger to the mother and fetus. Some of the problems that can arise if pain is not treated was stress in the mother which can stimulate the secretion of catecholamines. As a result of cotecolamine secretion in the mother will cause inadequate uterine contractions, the fetus is at risk of fetal distress due to decreased uteroplacental perfusion (Murray, 2007).

A related study was conducted by Afni (2018) that some mothers who gave birth felt severe pain, only $9-14 \%$ of women gave birth to experience mild pain without decreasing labor pain. Baker (2001) in Utami (2018), explained the results of a study conducted in the United Kingdom, of women who gave birth, found that $93.5 \%$ felt severe pain or unbearable pain. The results of other studies that support is Pratiwi (2015), found only 15\% of deliveries that took place without pain or mild pain, $35 \%$ of deliveries accompanied by moderate pain, $30 \%$ of deliveries accompanied by severe pain and $20 \%$ of deliveries accompanied by extreme pain.

In accordance with the theory put forward by Deasyana (2015), that the peak of pain occurs at the end of the first stage, namely the active phase where the opening becomes complete, reaching 10. As the opening increases, the pain and contractions get stronger, the pain comes from uterine contractions, so the contractions become more flexible, longer and stronger so that the pain felt more intense.

Thus it was expected that all mothers who will face childbirth to always be routine in conducting antenatal care visits. This is so that every mother can receive information provided by health workers, including preparation for mothers in the face of childbirth later. So that every mother who will give birth can have a picture of what will be experienced, including pain in childbirth.

\section{The percentage of maternal pain in the active phase I after giving heat compress hydotherapy}

Hydrotherapy is a technique / treatment of the body using the help of water (warm, hot, cold, water vapor, ice water) both silent and moving (in the form of currents / bursts of water that are generated electronically / naturally) can provide a stimulating effect on skin and muscle tissue with various advantages, among others: smooth circulation throughout the body through the effects of hydrostatic pressure on blood vessels and lymph,muscle relaxation, reduce nervous tension, and provide relaxation and rest (Wijayani, 2011). One nonpharmacological method for reducing pain is with hot compress hydrotherapy. Hot water used in hydrotherapy provides a local vasodilation effect that can increase muscle relaxation and reduce the sensation of pain due to muscle stress. With relaxation and comfort can reduce stress hormones. Increased comfort and decreased production of stress hormones can increase uterine contractility so that labor can be faster.

Several studies that use hydrotherapy in labor have proven that hydrotherapyable to reduce the use of tools in labor and does not require a longtime in women with dystocia. Hydrotherapy can increase relaxation. Based on this, hydrotherapy is a technique that can 


\section{STRADA Jurnal Ilmiah Kesehatan}

DOI: $10.30994 /$ sjik.v8i2.223

ISSN: 2252-3847 (print); 2614-350X (online)

Vol.8 No.2. November 2019. Page.136-145

be chosen to reduce pain, increase relaxation and comfort of birth mothers (Ika WidiAstuti, 2015).

Hot compresses are actions that use water or a heating device that aims to reduce pain during labor. Compress given to the lower back in the area where the head presses the spine will reduce pain, the heat generated will increase circulation to the area so that it opens circulation due to pressure). Implementation of hot compresses using a hot compress instrument (bladder) (Ratnaningsih, 2010).

Based on the study of research results relating to the provision of heat compresses in reducing labor pain, it can be identified several factors that influence the effectiveness of giving heat compresses in reducing labor pain, including the hot compresses in the lower abdomen to reduce pain because heat increases blood circulation thereby reducing anoxia tissue caused by contractions and tension. Hot compresses are appropriate for pain relief in some women. Based on the results of studies of the journals and articles above, a conclusion was found that the most effective heat compress media to reduce labor pain weas to use a cloth-coated bladder which can be a good conductor of heat to stabilize the water temperature in the bladder. compressed into the mother's lower back or stomach. So that it can be said that the bladder is covered with a good conductor of heat is one of the most effective media to compress heat in reducing labor pain. Hot compresses applied to a woman's lower back in the area where the fetal head is pressing against the spine will reduce pain. The heat will increase circulation to the area thereby improving tissue anoxia caused by pressure.

For this reason it was expected that health workers especially midwives and families can help reduce the discomfort of labor pain experienced by mothers by reducing labor pain with non-pharmacological techniques, one of which is by providing heat compress hydrotherapy.

Thi accordancethe research was Nikma Ayu (2014) who examined the Effect of Warm Compressing Techniques on Changes in Labor Pain Scale, which states that hydrotherapy with a warm compress technique has a use in reducing labor pain in in-patients especially in the first stage. Some studies that support this research are research by Felina (2015) which concludes that there was an effect of giving warm compresses and cold compresses to decrease the degree of labor pain. Deasyana Pratiwi, 2015 also stated that there were differences in the effectiveness of the conterpressure technique and warm compresses against pain reduction. Stage I The active phase which states that warm water compresses are very effective for the reduction of labor pain when I have active phases in labor.

The same thing was concluded by Ratnaningsih (2010), where the comparison of pre and post intervention in the treatment group showed a significant number of decreases in labor pain at the first stage with $p=0,000$. This showed that the heat compress was effectively used in pain during labor. This study wasline with research conducted by Manurung (2013) to got the result that there was a significant difference between the degree of pain before and after being given a hot compress with a value of $p=0.002$. MarwaniThiswasbe accordance with research conducted by Rita Afni 2018. It was also in accordance with the research of the Warm Compress for labor pain in DinceSafrinaPekanbaru got the result that there was an effect of giving a heat compress to the comfort of the mother in the active phase with the $\mathrm{p}$ value $=0.04$. This was consistent with research conducted by WijiUtami 2018 which examined the Effect of Warm Compress on labor pain in first stage active mothers in the Toroh I Health Center showed that there was a significant effect between giving hot compresses to labor pain in the active phase with the value of $p=0,000$ 


\section{STRADA Jurnal Ilmiah Kesehatan}

DOI: $10.30994 /$ sjik.v8i2.223

ISSN: 2252-3847 (print); 2614-350X (online)

Vol.8 No.2. November 2019. Page.136-145

The results also showed that mothers with severe pain as much as 2 respondents after being given hydrotherapy there were still experiencing severe pain. This shows that labor pain may also be influenced by other factors. Factors affecting labor pain include the age of very young women and older mothers complaining of higher labor pain levels, primiparas experienced greater pain at the beginning of labor, whereas multiparas experienced an increase in pain levels after delivery with a rapid decrease in the second stage of labor. , mothers who have small pelvis, large babies, babies with abnormal presentations, mothers who have a history of dysmenorrhoea may experience increased pain perception, possibly due to excess prostaglandin production, anxiety will increase individual response to pain, unpreparedness to undergo childbirth, support and companions for labor and social and cultural factors.

Therefore, as health workers, especially midwives and families to be able to help reduce labor pain experienced by mothers in various ways, including one by non-pharmacological ways, one of which was by giving heat compresses hidriterapi that had been proven effective to reduce labor pain in the mother so that labor can be run safely and smoothly.

\section{CONCLUSION}

Conclusion Hydrotherapy Giving heat compresses can affect the reduction of labor pain in the active phase I. It is recommended that heat compress hydrotherapy be used as onealternative to reduce the pain of friendship in mothers in the first phase of active phase.Suggestions There should be further research on the administration of hot compress hydrotherapy to the labor process in the second stage and other factors that influence labor pain in the first phase of active phase. Suggestions from researchers for research sites are for Research Sites to increase the role of health workers in the delivery room to better understand and apply non-farnakologi techniques such as hot compress hydrotherapy, while for respondents it is expected to provide information to maternity mothers and families about appropriate pain reduction safe and effective non-pharmacological methods to reduce pain during labor so as to provide comfort to the mother in the active phase.

\section{ACKNOWLEDGE}

Research researchers are entirely funded by the Directorate of Research and Community Service Directorate General of Research and Technology Strengthening Research and Technology Ministry and Higher Education in accordance with Research Contract Number: 113/SP2H/ LT/DRPM/2019. He also expressed his gratitude to the Puhjarak Health Center, Kediri Regency, for granting us permission to conduct research and facilitate the needs of this research.

\section{REFERENCES}

Afroh, F., Mohamad Judha, Sudarti. 2012. Teori Pengukuran Nyeri \& Nyeri Persalinan. Yogyakarta: NuhaMedika

Ardhiyanti, Y dan S. Susanti. 2016. Faktor yang Berhubungan denganKejadian Persalinan Lama di RSUD Arifin AchmadPekanbaru. Jurnak Kesehatan Komunitas, Vol.3, No.2, Mei2016

Brown, S. T., Douglas, C., \& Flood, L. P. (2001). Women's Evaluation of Intrapartum Non pharmacological Pain Relief Methods Used During Labor. The Journal of Perinatal Education; vol. 10, No. 3 tahun 2001 halaman1-8.

Pratiwi Deasyana, Wagiyo, Ulfa Nurullita. 2015. Perbedaan Efektifitas teknik 


\section{STRADA Jurnal Ilmiah Kesehatan}

DOI: $10.30994 /$ sjik.v8i2.223

ISSN: 2252-3847 (print); 2614-350X (online)

Vol.8 No.2. November 2019. Page.136-145

conterpressure dan kompres hangat terhadap penurunan nyeri Kala I Fase aktif di RSUD Sunan Kalijaga Demak. Jurnal Ilmiah Keperawatan dan Kebidanan (JIKK) 2015.

Felina, M., Masrul, Iryani, D. (2015). Pengaruh Kompres Panas dan Dingin terhadap Penurunan Nyeri Kala I Fase Aktif Persalinan Fisiologis Ibu Primipara. Jurnal Kesehatan Andalas. 4 (1):58-6

Hidayat, A.et.all. 2010. Asuhan Kebidanan Persalinan.Yogyakarta: NuhaMedika

Ika WidiA, Putu Ayu S, Desak Made W (2015). Pengaruh hydrotherapy dengan aplikasi kompres hangat terhadap nyeri persalinan kala 1 fase aktif. Bali : Universitas Udayana DenpasarBali

JNPK-KR. 2008. Asuhan persalinan Normal. Jaringan Nasional Pelatihan KlinikKesehatanReproduksi

JNPK-KR.2008. Buku AcuanPelatihan Klinik Asuhan Persalinan Normal Revisi 5. Edisi 2008. Departemen Kesehatan Republik Indonesia

Kepmenkes RI. 2013. Buku Saku Pelayanan kesehatan Ibu di Fasilitas Kesehatan Dasar dan Rujukan. WHO

Kuswanti, Ina. 2013. Askeb II Persalinan. Yogyakarta: Pustaka Pelajar

Nur Azizah. E. 2017. Pemberian Musik Gamelan Terhadap engurangan Nyeri Persalinan Kala I fase aktif

Nikma Ayu M, 2013. Pengaruh Tehnik Pemberian Kompres Hangat Terhadap Perubahan Skala Nyeri Persalinan. Jurnal Health Quality Vol. 4 No. 1, Nopember 2013, Hal. 1 $-76$

Manurung, S, dkk. (2013). Pengaruh Tehnik Pemberian Kompres Hangat Terhadap Perubahan Skala Nyeri Persalinan Pada Klien Primigravida. Journal Health Quality, 4 (1):1-8

Murray, S. S. And McKinney, E. S. (2007). Foundations of Maternal Newborn Nursing. 4 ed. Philippines:Saunders

Marwani.2017.Gambaran pengetahuan ibu bersalin kala I terhadap pemberian kompres air hangat dalam mengurangi rasa nyeri di RB Mitra Ananda Palembang tahun 2018. AkbidAlsuaibah Palembang, Jurnal Ilmiah AVICENNA Volume 14 nomor 1 April 2019, ISSN 1978 - 0664, EISSN 2654 - 3249, Volume 13 No.2, Juni2017

Mackey, M. M. (2001). Use of water in labor and birth. Clinical Obstetrics and Gynecology, 44, 733 - 749.

Martin, Reeder. 2011. Keperawatan Maternal Kesehatan Wanita, Bayi dan Keluarga eds. 18 vol. 1. Jakarta:EGC

Martin, Reeder. 2011. Keperawatan Maternal Kesehatan Wanita, Bayi dan Keluarga eds. 18 vol. 2. Jakarta:EGC

Putri, Adyb. 2015. Standar Operasional Prosedur Kompres Panas. https://putriadyb.wordpress.com/2015/06/ 19/standar-operasional-prosedur-danleaflet-typhoid/. (download : 27 April 2018)

Riwididko, H. 2012. Statistik Kesehatan. Jakarta: Mitra Cendekia Press

Ratnaningsih, M.D. (2010). Perbedaan Tingkat Nyeri Pada Ibu Bersalin Primipara Kala 1 Fase Aktif sebelun dan Setelah di Berikan Kompres Panas Kering (Buli-Buli Panas) di Rumah Bersalin Siti Khodijah Kabupaten Tegal. Semarang: Universitas MuhammadiyahSemarang.

Afni Rita, Rina Yulvina, Rissa Fitriani. 2018. Efektifitas Kompres Hangat terhadap nyeri persalinan di PMB DinceSafrinaPekanbaru. An Insyiroh Midwifery, Jurnal Ilmiah 


\section{STRADA Jurnal Ilmiah Kesehatan}

DOI: $10.30994 /$ sjik.v8i2.223

ISSN: 2252-3847 (print); 2614-350X (online)

Vol.8 No.2. November 2019. Page.136-145

Kebidanan (Jurnal of Midwifery Sciencies) Volume 7 nomor 2 Tahun 2018. http.//jurnal.alinsyirah.ac.id/index.php/ keb.

Sugiyono. 2012. Metode Penelitian Kuantitatif, Kualitatif, dan R\&D. Bandung:Alfabeta

Sulistyawati, A. 2013. Asuhan Kebidanan Pada Ibu Bersalin. Jakarta: Salemba Medika.

Winayah, Anis. 2013. Pengaruh Pemberian Musik Klasik Terhadap Intensitas Nyeri Persalinan Kala I Fase Aktif. Pare: AkbidPamenangKediri

Wong, Cathy. (2014). Different type sof hydrotherapy, online, http://altmedicine.about.com/od/therapiesfrometol/a/hydrotherapy.htm, diakses 19 April2018

Wijayani, Cinthya dan Tri Asih Pramasanti. 2011. Hidroterapi. https://updoc.tips/downloadFile/free-pdf-ebook-hidroterapi-cek. (download : 27 April 2018)

Utami Wiji, Rosmala Kurnia Dewi, Dian Ela Novitasari. 2018.Pengaruh Kompres Hangat terhadap nyeri persalinan pada ibu bersalin kala I Fase Aktif di Puskesmas Toroh I. AkbidAnnurPurwodadi, Jurnal Kesehatan Ibu dan Anak Akademi Kebidanan AnNur volume 3,Nomor 2. Desember 2018

Varney, Halen. 2007. Buku Ajar Asuhan Kebidanan vol 2 eds 4. Jakarta:EGC

Yuliatun, L. 2008. Penanganan Nyeri Persalinan dengan Metode Non Farmakologi. Malang: BayuMedia

Yanti. 2010. Buku Ajar Asuhan Kebidanan Persalinan. Yogyakarta: Pustaka Rihana 